\title{
What Next in Nuclear Power?
}

THE attempts to set the British nuclear industry to rights continue to meet with frustrating setbacks. Last week Clarke Chapman Ltd, one of the boilermakers which was to form part of the second nuclear company, decided that for the time being it was remaining independent. This means that the attempt by the Industrial Reorganization Corporation to create two companies has failed, at least for the time being. "We've fallen flat on our faces", an IRC man admitted.

It would be understandable if most readers of Nature were by now thoroughly confused by the combined attempts of the IRC, Ministry of Technology and other bodies to establish the new structure. On these grounds, a short history can be justified. Once there were three consortia, all busily bidding for power station contracts-ignoring the distant past, when there were four. But the market in Britain was too small to support them all, and the Ministry of Technology only liked companies that were big. So it was determined that at least one, and possibly two, should disappear, giving way to larger, stronger companies to compete for contracts all over the world.

One group of people, led by the Atomic Energy Authority, said that there should be only one large design and construction organization. Another group, which included the Central Electricity Generating Board, said that there should be at least two, to preserve domestic competition. So the House of Commons Sclect Committee on Science and Technology did some thinking. To start with, the Minister of Technology thought that there should be only one company, and he told members of the committec, privately, that it would be nice if they thought so too. By a narrow majority, they came up with the solution the minister wanted, but such are the vicissitudes of politics that he had by then changed his mind. Instead of using the report of the select committee to support him, as he had

\begin{tabular}{|c|c|c|}
\hline \multicolumn{3}{|c|}{ THE OLD NUCLEAR INDUSTRY } \\
\hline $\begin{array}{l}\text { John Thompson } \\
\text { Clarke Chapuan } \\
\text { A EII } \\
\text { Head Wrightson } \\
\text { Sir Robert } \\
\text { MacAlpine } \\
\text { C. A. Parsons } \\
\text { A. Reyrolle } \\
\text { Strachan and } \\
\text { Henshaw } \\
\text { Whessoc }\end{array}$ & $\begin{array}{l}\text { International } \\
\text { Combustion } \\
\text { Fairey } \\
\text { Engincering }\end{array}$ & $\begin{array}{l}\text { Babcock and } \\
\text { Wilcox } \\
\text { English Electric } \\
\text { Taylor Woodrow }\end{array}$ \\
\hline $\begin{array}{l}\text { Contracts: } \\
\text { Hinkley Point B } \\
\text { Hunterston } B\end{array}$ & Dungeness $\mathrm{B}$ & Wylfa (magnox) \\
\hline $\begin{array}{l}\text { Babcock English } \\
\text { Babcock and Wil } \\
\text { English Electric } \\
\text { Taylor Woodrow } \\
\text { IRC } \\
\text { AEA }\end{array}$ & $\begin{array}{l}\text { THE NEW-SO I } \\
\text { Glectric Nuclear } \\
\text { ox }\end{array}$ & \\
\hline $\begin{array}{l}\text { Contracts: } \\
\text { Hartlepools } \\
\text { PFR }\end{array}$ & & \\
\hline
\end{tabular}

originally intended, he had to pretend that it didn't count. He had evidently decided that the difficulties of squeezing three into one would be too difficult, even for the wizards of the IRC.

The decision was therefore taken to reduce the industry to two competing companies, and the IRC was given the task of organizing it. The first company, Babcock English Electric Nuclear Ltd, was created from one of the old consortia without much difficulty (partly because it needed the work). As a reward for being first, it won the contract for the Hartlepools nuclear station, an AGR (the first it had ever won). Actually, it was its turn for a contract, in any case, so not too much should be made of this. More significant was the fact that the AEA conceded the building of the prototype fast reactor to BEEN-quite a coup for the new company, which had never built anything more advanced than a magnox before. Some of those who have been designing and building the fast reactor are very upset by this decision.

Next the IRC got to work on the second company. Here the problem was to persuade three boilermakers - International Combustion Ltd, John Thompson and Clarke Chapman, to come together to form the nucleus of the company. All secms to have gone well until International Combustion admitted that it was in trouble with the contract at Dungeness $B$, the first commercial AGR. The actual work that will be involved may not be too expensive, but the delay to the completion of Dungeness B could well cost more than $£ \mathrm{I}$ million. 'Two other contracts on which ICL is engaged, for coal fired stations at Kingsnorth and Fiddler's Ferry, are also bchind schedule. 'There have been labour difficulties, particularly at Fiddler's Ferry, and ICL may not be liable for these. But faced with these uncertainties, Clarke Chapman evidently decided that the merger was too much of a risk just now.

The IRC now feels that there are two problems to be solved. First, some rapid work will have to be done at Dungeness, deciding what to do next. One rumour is that Atomic Power Constructions, responsible for the Dungeness contract, will call in Whessoe Ltd (which is a member of the Nuclear Power Group) to act as troubleshooters. Once the full extent of the delay can be forecast with more accuracy, Clarke Chapman may be persuaded to come back to the conference table. The IRC's second problem is to decide how the second company can be put together if the three boilermakers cannot agree on merger tcrms. The IRC is still talking in terms of a fow weeks, though others are less optimistic. 'Two possibilities have so far emerged. One is that a more limited merger, perhaps between John Thompson and Clarke Chapman (who already collaborate closely) could produce some of the bencfits of the full scale merger. It might later be possible for a merger to be arranged between the John 'Thompson' Clarke Chapman company and International Combustion. The same conclusion might ultimately emerge if the alternative approach were tried-that of a takeover of APC by 'TNPG. Tt is, however, far from clear how this last suggestion could be organized. Meanwhile the feeling at APC, beyond that of anxicty at the continuing uncertainty, is of determination to finish the Dungeness contract successfully. 